\title{
SINTESIS NANOPARTIKEL PERAK MENGGUNAKAN EKSTRAK KULIT BAWANG MERAH (Allium cepa L.) DAN UJI AKTIVITAS ANTIBAKTERI TERHADAP BAKTERI Staphylococcus aureus
}

\author{
Triyani Sumiati ${ }^{*}$, Devi Ratnasari², Dinda Dwi Mutiani ${ }^{3}$
}

\author{
1. Program Studi Farmasi Sekolah Tinggi Teknologi Industri dan Farmasi Bogor \\ 2. Program Studi Farmasi Sekolah Tinggi Teknologi Industri dan Farmasi Bogor \\ 3. Mahasiswa Program Studi S1 Farmasi Sekolah Tinggi Teknologi Industri dan Farmasi Bogor \\ Korespondensi: triyanisumiati@gmail.com
}

\begin{abstract}
ABSTRAK
Penelitian ini bertujuan untuk mensisntesis nanopartikel perak dan uji aktivitas nanopertikel perak terhadap bakteri Staphylococcus aureus.Nanopartikel perak (NPAg) disintesis menggunakan metode green synthesis dengan meraksikanekstrak kulit bawang merah (Allium cepaL.) dengan perak nitrat $\left(\mathrm{AgNO}_{3}\right)$.Sintesis NPAg dilakukan dengan memvariasikan konsentrasilarutan $\mathrm{AgNO}_{3}$ $0,1 \mathrm{mM}(\mathrm{F} 1) ; \quad 0,5 \mathrm{mM}(\mathrm{F} 2)$ dan $1,0 \mathrm{mM}(\mathrm{F} 3)$.Karakterisasi $\mathrm{NPAg}$ dilakukan menggunakan spektrofotometer UV-Vis, dan Particle Size Analyzer (PSA). Analisis menggunakan spektrofotometer UV-Vis menunjukkan bahwaNPAg pada F2 dan F3 berada pada kisaran panjang gelombang 400-500nm. Ukuran partikel diukur menggunakan PSA pada F1, F2 dan F3 berturutturut390,7nm, 62,34nm dan 50,63nm. Uji aktivitas antibakteri terhadap bakteri S.aureus dari F3, hasil menunjukkan bahwa aktivitasnya lebih baik dibandingkan larutan $\mathrm{AgNO}_{3}$ 1,0 mM yang tidak berukuran nanometer.
\end{abstract}

\section{Kata Kunci: Kulit bawang merah, nanopartikel perak, antibakteri}

\begin{abstract}
Synthesis of silver nanoparticle and determination of its antibacteial activity for Staphylococcus aureus were studied in this research. Silver nanoparticle (NPAg) were synthesized using method green synthesisby reacting extract peel of onion (Allium cepaL.) and silver nitrate $\left(\mathrm{AgNO}_{3}\right)$. NPAg synthesis used variation $\mathrm{AgNO}_{3} 0,1 \mathrm{mM}(\mathrm{F} 1) ; 0,5 \mathrm{mM}(\mathrm{F} 2)$ and $1,0 \mathrm{mM}(\mathrm{F} 3)$. Characterization using UV-Visible spektroscopy and Particle Size Analyzer (PSA). UV-Visible spektroscopy analysis showed that the NPAg at F2 and F3 in 400-500 nm wavelenght. The particle size used PSA at F1, F2 and F3 in $390,7 \mathrm{~nm}, 62,34 \mathrm{~nm}$ and $50,63 \mathrm{~nm}$. F3 has been tested for antibacteial activity S.aureus, the result showed that the antibacterial activity at $\mathrm{F} 3$ much better than $\mathrm{AgNO}_{3} 1,0 \mathrm{mM}$ which is not nanometer scale.
\end{abstract}

Keywords: Antibacterial, peel of onion, silver nanoparticle 


\section{PENDAHULUAN}

Nanoteknologi dapat didefinisikan sebagai partikel yang mempunyai ukuran 1-100 nm. Material berukuran nanometer memiliki sejumlah sifat kimia dan fisika yang lebih unggul dari material yang berukuran besar (bulk) [1]. Nanopartikel logam, seperti emas, perak, besi,zinc dan logam oksida merupakan salah satu nanoteknologi yang banyak dikembangkan[2].Nanopartikel perak banyak digunakan dalam bidang medis, Nanopartikel perak juga ditemukan sebagai aplikasi dalam salep topikal dankrim yang digunakan untuk mencegah infeksi luka bakar dan luka terbuka[3].

Metode yang digunakan untuk mensintesis nanopartikel perak yaitumetode sintesis secara fisika atau secara kimia, sehingga didapatkan nanopartikel dengan bentuk, ukuran dan komposisi yangdiinginkan. Sebagian besar metode fisika dan metode kimia yang digunakan untuk sintesis dan produksi nanopartikel perak mahal dan tidak ramah lingkungan [4]. Melihat kekurangan kedua metode tersebut maka perlu dilakukan suatu inovasi metode sintesis yangpengembangannya sederhana, biokompatibel, tidak beracun, dan ramah lingkungan [5].

Metode yang dikembangkan oleh banyak peneliti adalah green synthesis. Green synthesis adalah metode sintesis nanopartikel dengan memanfaatkan agen biologi salah satunya menggunakan ekstrak tanaman [6]. Prinsipnya proses sintesis nanopartikel yaitu dengan memanfaatkan senyawa-senyawa organik yang terkandung dalam tanaman untuk mereduksi ion logam.Biosintesis nanopartikel diduga melibatkan senyawa-senyawa metabolit sekunder dari tumbuhan, seperti flavonoid, triterpenoid, polifenol dan kuersetin [7].

Kulit bawang merah merupakan salah satu tanaman yang diketahui memiliki kandungan senyawa metebolit sekunder diantaranya flavonoid, saponin, tanin, dan polifenol [8]. akan dilakukan penelitian dengan mensintesis nanopartikel perak menggunakan ekstrak kulit bawang merah dengan menggunakan metode green synthesis.Nanopartikel perak terbukti efisien dan baik sebagai antibakteri [9], sehingga dilakukan pengujian aktivitas antibakteri terhadap bakteri Staphylococcus aureusdengan menggunakan metode cakram.

\section{Bahan dan Metode}

Bahan-bahan yang digunakan meliputi kulit bawang merah, aquadest, $\mathrm{AgNO}_{3}$, nutrient broth (NB), nutrient agar (NA), dan suspensi bakteri Staphyloccocus aureus.

Alat-alat yang digunakan meluputi alatalat gelas (Pyrex), spektrofotometer UV-Vis (Shimadzu), Particle size analizer (Malvern), Magnetic stirrer (IKA), kertas cakram, cawan petri, inkubator, autoklaf.

\section{Preparasi Sampel}

Kulit bawang merah yang akan digunakan dicuci dan dikeringkan kemudian dihaluskan lalu diayak. Sebanyak 25 gram serbuk kering kulit bawang merahdilarutkan dalam $100 \mathrm{ml}$ aquadest lalu dipanaskan hingga suhu $50^{\circ} \mathrm{C}$ dan dilanjutkan perebusan selama 10 menit kemudian didinginkan. Setelah mencapai suhu $25^{\circ} \mathrm{C}$, air rebusan disaring. Air rebusan tersebut selanjutnya dapat digunakan langsung sebagai sampel untuk proses biosintesis.

Larutan perak nitrat $\left(\mathrm{AgNO}_{3}\right)$ dibuat variasi konsentrasi $0,1 \mathrm{mM}(\mathrm{F} 1) ; 0,5 \mathrm{mM}(\mathrm{F} 2)$; dan 1,0 mM (F3). Larutan $\mathrm{AgNO}_{3} \quad 1,0 \mathrm{mM}$ sebagai larutan induk, dibuat dengan melarutkan $85 \mathrm{mg}$ serbuk $\mathrm{AgNO}_{3}$ dengan aquadest dalam labu ukur $500 \mathrm{~mL}$ hingga tanda batas dandihomogenkan. Dilakukan pengenceran dari larutan induk sehingga diperoleh larutan $\mathrm{AgNO}_{3}$ dengan konsentasi larutan sebesar 0,1 mM dan 0,5 mM.

\section{Sintesis Nanopartikel Perak}

Sintesis nanopartikel perak akan dilakukan dengan mengadopsi metode yang digunakan oleh[10]dengan sedikit modifikasi. Sintesisdilakukan dengan mencampur $50 \mathrm{~mL}$ larutan $\mathrm{AgNO}_{3}$ dan $5 \mathrm{~mL}$ rebusankulit bawang merah. Campuran larutan tersebut diaduk menggunakan magnetik stirer pada kecepatan $150 \mathrm{rpm}$ dengan pemanasan pada suhu $50^{\circ} \mathrm{C}$ selama 20 menit, kemudian diamati perubahan warna. Sebagai indikator telahterbentuknya nanopartikel perak secara visual adalah adanya perubahan warna larutan dari bening menjadi kekuningan hingga kecokelatan. Perubahan warna diamati setiap 20 menit.

\section{Pengujian Aktivitas Antibakteri}

Bakteri ujiStaphyloccocus aureusyang telah disuspensikan dalam media NB kemudian diinokulasikan sebanyak $0,2 \mathrm{ml}$ kedalam media NA $200 \mathrm{ml}$ yang telah steril. Media NA yang 
telah berisi kultur bakteri di tuang ke dalam cawan petri steril sebanyak $20 \mathrm{ml}$ dan dibiarkan menjadi padat.Setelah memadat,diletakkan kertas cakram dan diteteskan dengan larutan uji sebanyak $10 \mu \mathrm{l}$, dibuat $3 \mathrm{x}$ pengulangan. Cawan petri kemudian di inkubasi pada suhu $37^{\circ} \mathrm{C}$ selama 24 jam. Pengukuran zona hambat diukur menggunakan jangka sorong.

\section{HASIL DAN PEMBAHASAN}

\section{Sintesis Nanopartikel Perak}

Sintesis nanopartikel perak menggunakan reduktor dari ekstrak kulit bawang merahdicampurkan dengan larutan perak $\mathrm{AgNO}_{3}$, dipanaskan dengan suhu $60^{\circ} \mathrm{Cdisertai}$ dengan pengadukan selama 20 menit dan didinginkan sampai suhu ruangan. Proses pemanasan dan pengadukan tersebut bertujuan untuk mempercepat pembentukan nanopartikel perak.

Salah satu indikator terbentuknya nanopartikel perak dalam larutan ini ditandai dengan adanya perubahan warna dari kekuningan hingga cokelat kemerahan seiring bertambahnya waktu.Terjadinya perubahan warna koloid pada pembentukan nanopartikel perak disebabkan oleh proses oksidasi reduksi[11].Senyawa organik yang diduga flavonoid yang terdapat pada ekstrak kulit bawang merah berperan sebagai agen pereduksi yang mereduksi $\mathrm{Ag}^{+}$menjadi $\mathrm{Ag}^{0}$. Warna awal campuran ekstrak dan $\mathrm{AgNO}_{3}$ adalah kuning muda dan berubah menjadi kuning tua, cokelat kemerahan, hingga cokelat pekat.

Warna yang terbentuk dari proses sintesis nanopartikel perak berasal dari senyawa organik yang teroksidasi. Semakin pekat warna yang dihasilkan menunjukkan semakin banyak senyawa organik yang teroksidasi dan semakin banyak pula $\mathrm{Ag}^{+}$yang mengalami reduksi menjadi $\mathrm{Ag}^{0}$, sehingga semakin banyak nanopartikel perak yang terbentuk [3].

Perubahan warna larutan padaF1 dari menit ke 0 sampai menit ke 140 tidak mengalami perubahan warna menjadi kecokelatan. Proses sintesis F2 pada menit ke40 hingga menit ke-140 warna larutan F2 menjadi kecokelatan. Hasil sintesis F3 pada menit ke-20 menjadi menjadi kecokelatan sampai menit ke-140 warna kecokelatan menjadi semakin pekat. Hal tersebut dikarenakan adanya variasikonsentrasi larutan $\mathrm{AgNO}_{3}$ dalam proses sintesis nanopartikel perak sehingga warna yang dihasilkan juga berbeda-beda.

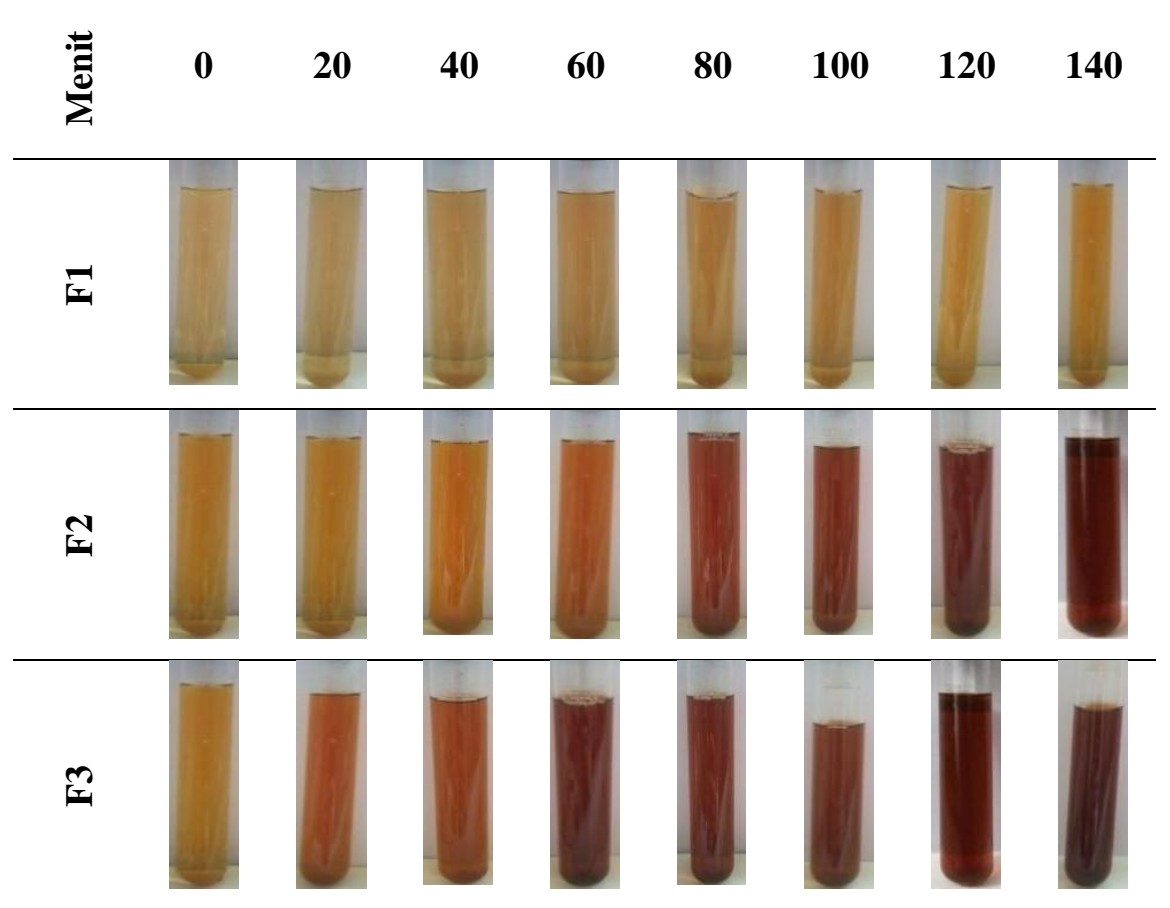

Gambar 1. Perubahan Warna Sintesis Nanopartikel Perak 


\section{Hasil Analisis Spektrofotometri $U V$-Vis}

Analisis spektrofotometer $\quad U V$-Vis digunakan untuk mengkonfirmasi pembentukan nanopartikel dari hasil sintesis.Pengukuran absorbansi dan $\lambda_{\text {maks }}$ nanopartikel perak menggunakan spektrofotometer $U V$-Vis dilakukan pada rentang panjang gelombang 200-800 nm.

Proses sintesis nanopartikel perak, dengan pengamatan dilakukan selama 140 menit dan diukur setiap 20menit.

Pengukuran spektrum panjang gelombang maksimum $\left(\lambda_{\text {maks }}\right)$ dapat menunjukkan sebaran ukuran dari nanopartikel yang dihasilkan [12]. Berdasarkan hasil pengukuran $\lambda_{\text {maks }} \mathrm{F} 1$ pada menit ke-0 hingga menit ke-140, serapan maksimum diperoleh pada panjang gelombang berkisar 283-274nm. Pada F2 dan F3 dari menit ke-20 hingga menit ke-140 berturut-turut sebesar 414-430 nm, dan 416-435 nm.

Nanopartikel perak telah terbentuk apabila memiliki serapan maksimum pada panjang gelombang antara $400 \mathrm{~nm}$ hingga $500 \mathrm{~nm}$ [12]. Berdasarkan hasil pengamatan panjang gelombang maksimum dapat disimpulkan bahwa F1 tidak menunjukkan adanya nanopartikel perak yang terbentuk, karena $\lambda_{\text {maks }}$ yang dihasilkan berada dibawah $400 \mathrm{~nm}$. Hasil panjang gelombang maksimum yang didapatkan F2 dan F3 pada menit ke-20 berada di kisaran 400-500 $\mathrm{nm}$, hal ini menandakan bahwa pada F2 dan F3 nanopartikel perak mulai terbentuk pada menit ke-20.

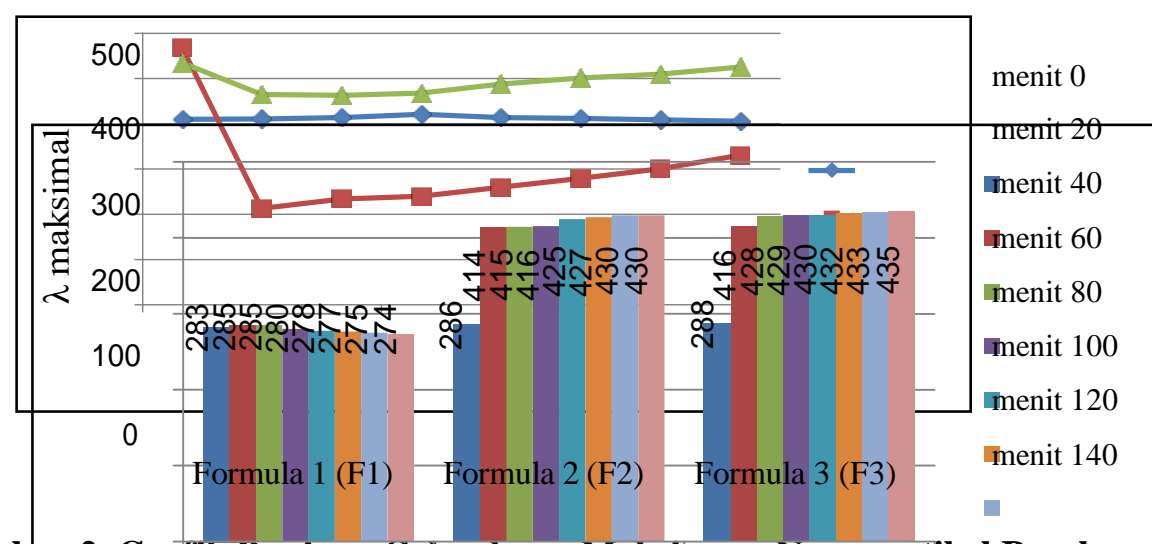

Gambar 2. Grafik Panjang Gelombang Maksimum Nanopartike!-Perak

\begin{abstract}
Nilai absorbansi yang dihasilkan pada bertambahnya waktw kontak.Nilai-absorbansi analisis spektrofotometer $U V$-Vis dapat yang meningkat merupakan indikator bahwa digunakan untuk memprediksi jumlah nanopartikel perak yang terbentuk semakin nanopartikel perak yang terbentuk [12]. bertambah [13]. Hasil penelitian menunjukkan Berdasarkan hasil penelitian nilai absorbansi bahwa F2 dan F3 menghasilkan nilai absorbansi yang didapatkan pada F1 dari menit ke 0 hingga yang semakin besar dengan seiringnya menit ke 140 tidak megalami kenaikan yang bertambah waktu kontak hal ini menandakan signifikan. Pada F2 dan F3 nilai absorbansi bahwa semakin bertambahnya waktu kontak pada menit ke 20 hingga menit ke 140 semakin jumlah nanopartikel perak yang terbentuk besar. Saat terbentuk nanopartikel perak, nilai semakin banyak.
\end{abstract} absorbansi semakin besar dengan semakin

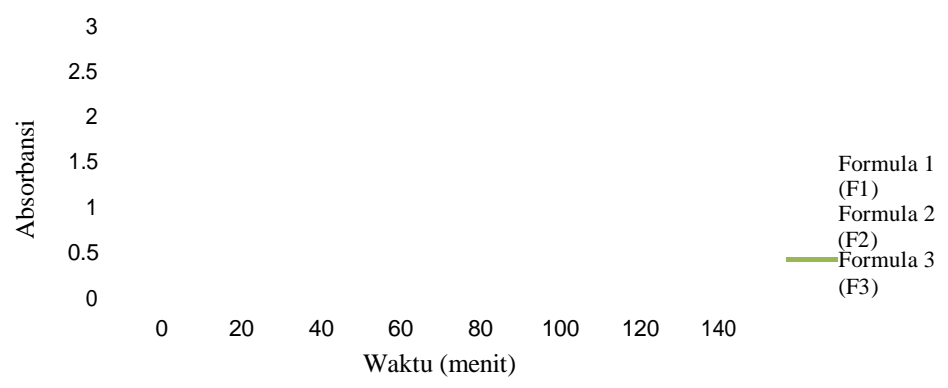

Gambar 3. Grafik Pengukuran Absorbansi Nanopartikel Perak 
Penentuan Ukuran Partikel \& Zeta Potensial

Ukuran nanopartikel perakdari hasil sintesis nanopartikel perak di analisis menggunakan Particle Size Analyzer (PSA).Analisis ukuran partikel (PSA) digunakan untuk menggambarkan distribusi ukuran partikel

Tabel 1. Data Ukuran Partikel dan Zeta Potensial Nanopartikel Perak

\begin{tabular}{ccc}
\hline Formula & Ukuran Partikel & Zeta Potensial \\
\hline Formula 1 & $390,7 \mathrm{~nm}$ & $-29,3 \mathrm{mV}$ \\
Formula 2 & $62,34 \mathrm{~nm}$ & $-14,6 \mathrm{mV}$ \\
Formula 3 & $50,63 \mathrm{~nm}$ & $-19,7 \mathrm{mV}$
\end{tabular}

Pengujian zeta potensial bertujuan untuk melihat kestabilan nanopartikel perak. Nilai zeta potensial yang baik yaitu $\pm 30 \mathrm{mV}$. Berdasarkan tabel 1 diketahui bahwa nilai zeta potensial untuk F1, F2 dan F3 kurang dari \pm 30 $\mathrm{mV}$, hal tersebut menunjukkan semakin rendah nilai zeta potensial maka daya tarik menarik muatan antar partikel dispersi melebihi daya tolak menolaknya hingga terjadi agregasi/penyatuan antar partikel.Nilai negatif yang didapat menandakan nanopartikel perak bersifat basa. Kestabilan nanopartikel perak dapat ditingkatkan dengan menggunakan agen penstabil untuk mencegah aglomerasi seperti polianilin, poliakrilonitril, polietilen glikol, polisakarida, selulosa, gelatin, dan kanji [14].

\section{Pengujian Aktivitas Antibakteri Nanopartikel Perak}

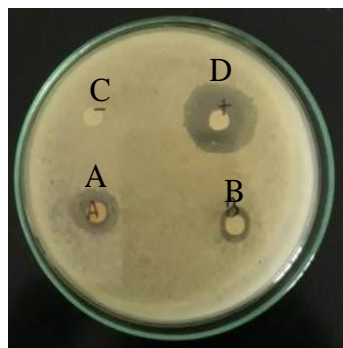

Ulangan I

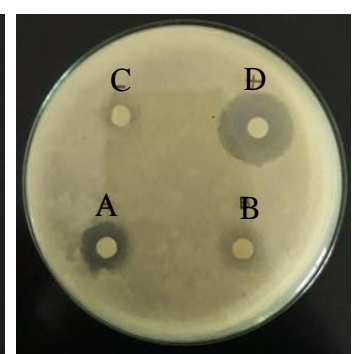

Ulangan II
Nanopartikel perak yang terbentuk selanjutnya diuji terhadap bakteri Staphyloccocus aureus. Pengujian aktivitas antibakteri dilakukan dengan Formula nanopartikel terpilih yaitu formula yang menghasilkan ukuran terkecil yaitu nanopartikel perak NPAg 1,0 mM yang terdapat pada F3. Selanjutnya, formula yang terpilih tersebut akan dibandingkan aktivitas antibakteri dengan larutan $\mathrm{AgNO}_{3}$ 1,0 mM. Pengujian ini bertujuan untuk mengetahui apakah ukuran partikelmemiliki pengaruh aktivitas antibakteri. Kontrol positif yang digunakan yaitu kloramfenikol. Kontrol negatif yang digunakan yaitu aquadest steril. Aktivitas dari nanopartikel perak terhadap bakteri Staphyloccocus aureus ditunjukkan dengan timbulya zona hambat pertumbuhan pada bakteri.

Keterangan: $\mathrm{A}=\mathrm{NP} \mathrm{AgNO}_{3} 1,0 \mathrm{mM}$

$\mathrm{B}=\mathrm{AgNO}_{3} 1,0 \mathrm{mM}$

$\mathrm{C}=$ Kontrol -

$\mathrm{D}=$ Kontrol +

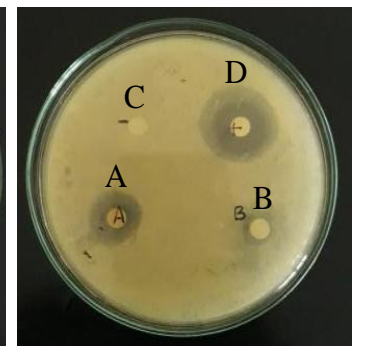

Ulangan III

Gambar 4. Zona Hambat Nanopartikel Perak 
Tabel 2. Hasil Uji Statistik Nanopartikel Perak terhadap bakteri Staphyloccocus aureus

\begin{tabular}{cc}
\hline Larutan Uji & Diameter Zona Hambat \\
\hline $\mathrm{NP} \mathrm{AgNO}_{3} 1,0 \mathrm{mM}$ & $11,0833^{\mathrm{b}}$ \\
$\mathrm{AgNO}_{3} 1,0 \mathrm{mM}$ & $5,5067^{\mathrm{c}}$ \\
$\mathrm{Kontrol}+$ & $18,2533^{\mathrm{d}}$ \\
Kontrol - & $0,0000^{\mathrm{a}}$ \\
\hline
\end{tabular}

Keterangan : notasi a,b,c,d merupakan hasil dari uji Duncan. Apabila pada kolom yang sama, notasi Duncan ditulis dengan huruf yang sama maka menunjukan konsentrasi nanopartikel perak tidak berbeda signifikan

Berdasarkan uji statistik menggunakan Anova yang dilanjutkan dengan uji Duncan dapat diketahui bahwa terdapat perbedaaan yang nyata pada masing-masing pengujian. Hal tersebut didasari karena terdapatnotasi huruf yang berbeda pada tiap kolom, hal ini menyatakan terdapat perbedaan yang signifikan antar perlakuan.

Berdasarkan uji statistik antara NPAg 1,0 mM dan larutan $\mathrm{AgNO}_{3} \quad 1,0 \mathrm{mM}$ dapat diketahui bahwa keduanya memiliki perbedaan yang nyata dalam menghambat pertumbuhan bakteri Staphyloccocus aureus. Hal tersebut membuktikan bahwa perbedaan ukuran partikel dapat menyebabkan perbedaan aktivitas antibakteri, dimana perak dengan ukuran nanometer terbukti memiliki aktivitas yang lebih baik sebagai antibakteri dibandingkan dengan perak yang tidak berukuran nanometer.

Nanopartikel perak (NPAg) sebagai antibakteri memiliki kemampuan dalam menghambat pertumbuhan bakteri dikarenakan memiliki ukuran yang kecil dan luas permukaan yang besar memungkinkan untuk kontak dengan permukaan mikroorganisme dengan sangat baik. Mekanisme NPAg sebagai antibakteri adalah pada saat proses difusi berlangsung, NPAg mendekat pada membran sel bakteri dan melakukan penetrasi kedalam bakteri. Partikel NPAg akan berinteraksi dengan fosfor dan sulfur yang terkandung pada DNA, sehingga menyebabkan kerusakan pada sel mikroba. Interaksi ini menyebabkan DNA akan kehilangan kemampuan replikasi, mencegah pembelahan sel dan pertumbuhan sel mikroba sehingga pada akhirnya sel tersebut menjadi mati [15].

\section{SIMPULAN}

Berdasarkan hasil penelitian maka dapat disimpulkan sebagai berikut :
1. Limbah ekstrak kulit bawang merah dapat dimanfaatkan sebagai agen pereduksi ion $\mathrm{Ag}^{+}$menjadi $\mathrm{Ag}^{\mathrm{O}}$.

2 Analisis ukuran partikel (PSA) menunjukkan F1, F2 dan F3 berturut-turut sebesar $390,7 \mathrm{~nm}, 62,34 \mathrm{~nm}$ dan 50,63 nm.

3. Nilai zeta potensial yang diperoleh pada F1, F2 dan F3 berturut-turut sebesar -29,3 mV, 14,6 $\mathrm{mV}$ dan $-19,7 \mathrm{mV}$ menunjukkan bahwa ketiga formula tersebut belum stabil, sehingga kemungkinan dapat terjadi aglomerasi.

4. Diameter zona hambat masing-masing nanopartikel perak (NP) $\mathrm{AgNO}_{3} 1,0 \mathrm{mM}$ (F3) sebesar 11,08 mm dan larutan $\mathrm{AgNO}_{3}$ $1,0 \mathrm{mM}$ sebesar 5,5 mm. Hal tersebut membuktikan bahwa perak yang berukuran nanometer memiliki aktivitas antibakteri yang lebih baik dibandingkan dengan perak yang tidak berukuran nanometer

\section{SARAN}

1. Perlu dilakukan optimasi jumlah ekstrak kulit bawang merah sebagai peraduksi ion $\mathrm{Ag}^{+}$.

2 Perlu ditambahkan suatu zat yang dapat menstabilkan nanopartikel perak yang telah terbentuk.

3. Perlu dilakukan karakteristik lebih lanjut terkait sintesis nanopartikel perak menggunakan kult bawang merah (Allium cepa $\mathrm{L}$.).

\section{DAFTAR PUSTAKA}

[1] Abdullah, M \& Khairurijal. 2010. Karakterisasi Nanomaterial: Teori, Penerapan, dan Pengolahan Data. Bandung: CV. Rezeki Putera Bandung.

[2] Prasad, S.B. 2013. Current Understanding of Synthesis and Pharmacological Aspects of Silver Nanoparticles.American Journal of 
Phytomedicineand

Therapeutics.1(7): 536-547

[3] Elumalai, E.K., T.N.K.V. Prasad, P.C.

Nagajyothi dan E. David. 2011. A

Bird"seye view on Biogenic Silver nanoparticles and Their Application.Pelagia Research Library, 2(2): 88-97.

[4] Tolaymat, T.M., Amro, M.E.B., Ash, G., Kirk, G.,Scheckel., Todd, P.L., Makram, S. 2010. An Evidence Based Environmental Perspective Of Manufactured Silver Nanoparticle In Syntheses And Applications : A Systematis Review And Cricital Appraisal Of Peer Reviewed Scientific Papers. Sciences of Total Environment 408: 999-1006.

[5] Ramya, M.,\& Subapriya, M. S. 2012. Green Synthesis Of Silver Nanoparticles.Int J Pharm Med Biol Sci 1:54-61.

[6] Kumar, P., Singh, P., Kumari, K., Mozumdar, S., Chandra, R.A. 2011. GreenApproach For The Synthesis Of Gold Nano Triangles Using Aqueous LeafExtract Of Callistemon Viminalis. Mater Lett 65:595-597.

[7] Akhtar, M.S., Jitendra, P., Yun, S.Y. 2013.Biogenic Synthesis Of Metallic Nanoparticles By Plant Extracts. American Chemical SocietySustainable Chemistry and Engineering.

[8] Singh, B.N., Singh, B.R., Singh, R.L., Prakash, D., Singh, D.P., Sarma, B.K. 2009.Polyphenolics from various extracts/fractions of red onion (Allium cepa) peel withpotent antioxidant and antimutagenic activities.Food and Chemical Toxicology, 47,450-452.

[9] Niraimathi, K.L., Sudha, V., Lavanya, R., Brindha, P. 2012. Biosynthesis Of Silver Nanoparticles Using Alternanthera Sessilis (Linn.) Extract AndTheir Antimicrobial, Antioxidant Activities. Colloids and Surfaces B: Biointerfaces 02 (2013) 288- 29
[10] Saxena, A., Tripathi, R.M., Singh, R.P. 2010. Biological Synthesis Of Silver Nanoparticles By Using Onion (Allium Cepa) Extract And Their Antibacterial Activity.Digest Journal of Nanomaterials and Biostructures Vol. 5, No 2, p. $427-432$.

[11] Haryani, Y., Ganis, K., Yuharmen., Eka, M. Putri., Dhia, T. A., Yonatha, M.2016. Pemanfaatan Ekstrak Air Rimpang Jahe Merah (Zingiber Officinale Linn. Var. Rubrum) Pada Biosintesis Sederhana Nanopartikel Perak. Pekanbaru: Universitas Riau.

[12] Solomon, S.D., Bahadory, M., Jeyarajasingam, A.V., Rutkowsky, S.A., Boritz, C. 2007. Syntesis and study of silver nanoparticles. Journal of Chemical Education, Vol. 84 (No.2), 322-325.

[13] Handayani, W., Bakir, I. Dan Purbaningsihs. 2010. Potensi Ekstrak Beberapa Jenis Tumbuhan Sebagai Agen Pereduksi Untuk Biosintesis Nanopartikel Perak. Seminar Nasional Biologi Universitas Gajah Mada. Yogyakarta.

[14] Ravindran, P.N., Babu, K.N. \& K.N. Shiva. 2005. Botany and Crop Improvement of ginger. Di dalam: Ravindran, P.N. \& Babu, K.N. (eds). Ginger: The Genus Zingiber. Florida: CRC Press.

[15] Nalawati, A.N. 2015. Sintesis Nanopartikel Perak (NPAg) Dengan Metode Yang Ramah Lingkungan Dan Kajian Aktifitasnya Dalam Menghambat Pertumbuhan Bakteri Gram Positif Dan Bakteri Gram Negatif. Institut Pertanian Bogor. 